\title{
Effect of $\beta$-lactam antibiotics on plant regeneration in carrot protoplast cultures
}

\author{
Ewa Grzebelus • Lukasz Skop
}

Received: 9 January 2014 / Accepted: 6 June 2014 / Published online: 4 July 2014 / Editor: John Forster

(C) The Society for In Vitro Biology 2014. This article is published with open access at Springerlink.com

\begin{abstract}
Protoplasts of three carrot cultivars were isolated from in vitro-grown plantlets by overnight incubation in an enzyme mixture composed of $1 \%(w / v)$ cellulase Onozuka $\mathrm{R}-10$ and $0.1 \%(w / v)$ pectolyase $\mathrm{Y}-23$. After cell immobilization in modified thin alginate layers, three types of $\beta$-lactam antibiotics (cefotaxime, carbenicillin, or timentin) at five different concentrations $\left(100,200,300,400\right.$, or $\left.500 \mathrm{mg} \mathrm{L}^{-1}\right)$ were added to the culture medium. In 20-d-old cultures, a different number of cell colonies had formed and varied on average from 27 to $56 \%$ in carbenicillin- and cefotaximecontaining media, respectively. Supplementation of the culture media with antibiotics at concentrations higher than $100 \mathrm{mg} \mathrm{L}^{-1}$ resulted in a decrease in plating efficiency in comparison with the controls. However, from all antibiotic treatments, except carbenicillin at concentrations of 400$500 \mathrm{mg} \mathrm{L}^{-1}$, efficient plant regeneration occurred. For this reason, we believe that cefotaxime and timentin in the concentrations analyzed here may be used in complex in vitro procedures or valuable carrot cultures as a prophylactic agent for prevention against occasional contaminations.
\end{abstract}

Keywords Daucus carota · Carbenicillin · Cefotaxime · Somatic embryogenesis $\cdot$ Timentin

\section{Introduction}

Plant protoplast technology can be widely used in various aspects of plant science to study such fundamental processes as differentiation, dedifferentiation, and pluripotency of cells

\section{E. Grzebelus $(\bowtie) \cdot$ L. Skop}

Institute of Plant Biology and Biotechnology, Faculty of Horticulture,

University of Agriculture in Krakow, Al. 29 Listopada 54,

31-425 Krakow, Poland

e-mail: e.grzebelus@ogr.ur.krakow.pl (reviewed in Jiang et al. 2013), and to introduce novel characteristics in commercial crops. Conventional breeding tools may incorporate different techniques exploring protoplast culture, including micropropagation, in vitro selection, genetic transformation, and, particularly, somatic hybridization (reviewed in Davey et al. 2005a). Systems based on protoplast culture contain many steps and include time-consuming procedures as follows: (1) induction of in vitro-grown donor material; (2) source tissue slicing, conditioning, and digestion; (3) protoplast isolation and purification; (4) for some species, embedding of the cells before culture; and finally, (5) plant regeneration preceded with stepwise reduction of the osmotic pressure by diluting the medium (Davey et al. 2005b). Microbial contamination caused by bacteria, yeasts, and fungi introduced at any of these steps can become a serious problem, especially when it occurs on rare, valuable, or irreplaceable cultures. As a result, a reduced growth rate is observed usually leading to cell/tissue/plant death, which eliminate the cultures completely from the program, and the long procedure of donor material establishment, protoplast isolation, or their regeneration into plants must be started again (Leifert and Waites 1992; Shehata et al. 2010).

Contamination introduced to in vitro cultures can be exogenous or endogenous originating from explant surfaces, intracellular spaces within the plant tissues, or poor aseptic conditions during manipulation in laminar flow hoods (Shehata et al. 2010). They may express themselves immediately or can remain latent for a long period of time, which makes them extremely difficult to control (Leifert and Cassells 2001). Contamination losses during the in vitro stages of plant tissue culture may be substantially reduced or eliminated by using antimicrobial treatments such as antibiotics (Abdi et al. 2008). Despite their common and successful application to minimize bacterial growth in animal cell culture, they are frequently phytotoxic and may differently affect the regeneration ability in plant cell and tissue culture (Pollock et al. 1983; Abdi et al. 
2008). Antibiotics were shown either to retard/inhibit (da Silva and Fukai 2003; da Silva Mendes et al. 2009; Qin et al. 2011) or stimulate explant growth and development (Costa et al. 2000; Mittal et al. 2009; Shehata et al. 2010). Their role in affecting the developmental events is not well understood, but it has been assumed that the antibiotics mimic plant hormones since some of them possess an auxin-like structure (Grewal et al. 2006; Qin et al. 2011). Plant sensitivity to antibiotics usually is species-specific and mainly depends on growth conditions, explant type, and culture system (Qin et al. 2011). Therefore, before their application to the culture in order to prevent, minimize, or eliminate unwanted microorganisms, it is necessary to screen the type and concentration of antibiotics with the least phytotoxic effects on plant tissues and cells.

To suppress or eliminate gram-negative and/or grampositive bacteria infecting in vitro cultures, antibiotics with a broad spectrum of microbiological activity and with little or no detrimental effect on plant growth and regeneration should be used (Cheng et al. 1998). $\beta$-Lactam antibiotics such as carbenicillin (belonging to the penicillin group [Holford and Newbury 1992]), cefotaxime (a semisynthetic analog of cephalosporin [Danilova and Dolgikh 2004]), and, recently, timentin (a mixture of a penicillin derivative ticarcillin and clavulanic acid [Nauerby et al. 1997]) are most commonly used to control bacterial growth in plant tissue culture particularly after Agrobacterium-mediated transformation (Tang et al. 2000; Ogawa and Mii 2004; da Silva Mendes et al. 2009; Qin et al. 2011). It is known that $\beta$-lactams interfering with penicillin-binding proteins in the bacterial periplasm inhibit the biosynthesis of peptidoglycan - a specific component of the prokaryotic cell wall that in consequence provokes bacterial death by cell wall lysis (Nauerby et al. 1997; Ogawa and Mii 2004). The effect of $\beta$-lactam antibiotics on the development of such sensitive structures as plant protoplasts has rarely been investigated, especially at high concentrations, which are usually required to control microbial infections in culture systems (Simmonds and Grainger 1993; Teng and Nicholson 1997). To our knowledge, there are only a few reports showing the influence of selected antibiotics on protoplast cultures of Antirrhinum majus, Pisum sativum, and Nicotiana tabacum (Watts and King 1973); Nicotiana plumbaginifolia (Pollock et al. 1983); Passiflora edulis (d'Utra Vaz et al. 1993); Triticum aestivum (Simmonds and Grainger 1993); and Allium longicuspis (Fellner 1995). It seems that carrot (Daucus carota L. ssp. sativus Hoffm., $2 n=2 x=18$ ), a model species for plant tissue culture systems and one of the most important vegetable crops in Apiaceae family, has not been investigated in this context. Therefore, the objective of the present study was to compare the effects of three $\beta$-lactam antibiotics, carbenicillin, cefotaxime, and timentin, in different concentrations on plant regeneration capacity, in carrot protoplast cultures in order to define those which were less toxic to plant cells for prophylactic use against bacterial contamination in procedures based on protoplast isolation and culture.

\section{Materials and Methods}

Plant material. Three open-pollinated carrot (D. carota L. ssp. sativus Hoffm.) cultivars were used as donors for protoplast isolation: 'Dolanka', 'Amsterdamska', and 'Koral' (all provided by Polan-Polish seed company). Protoplasts were isolated from in vitro-grown plantlets derived from seeds as described previously by Grzebelus et al. (2012). Briefly, seeds were germinated in vitro after surface sterilization with a three-step procedure including incubation (1) in a water bath at $40^{\circ} \mathrm{C}$, then $(2)$ in $0.2 \%(v / v)$ solution of fungicide 'Bravo' (Syngenta, Waterford, Ireland), and finally (3) in 20\% (w/v) solution of chloramine $\mathrm{T}$ trihydrate (N-chloro-ptoluenesulfonamide sodium salt) $30 \mathrm{~min}$ each, followed by three rinses with sterile distilled water. After air-drying on a filter paper, the seeds were placed in Petri dishes on solid Murashige and Skoog (MS) medium with vitamins (Murashige and Skoog 1962) supplemented with $30 \mathrm{~g} \mathrm{~L}^{-1}$ sucrose and $6.5 \mathrm{~g} \mathrm{~L}^{-1}$ plant agar (Biocorp, Warszawa, Poland) and incubated at $26 \pm 2{ }^{\circ} \mathrm{C}$ in the dark. After approximately $1 \mathrm{wk}$ of culture, seedlings were transferred to glass jars containing regeneration medium $(\mathrm{R})$ composed of MS macro- and micro-elements, $0.1 \mathrm{mg} \mathrm{L}^{-1}$ thiamine $\mathrm{HCl}, 0.1 \mathrm{mg} \mathrm{L}^{-1}$ pyridoxine $\mathrm{HCl}, 0.5 \mathrm{mg} \mathrm{L}^{-1}$ nicotinic acid, $3.0 \mathrm{mg} \mathrm{L}^{-1}$ glycine, $100 \mathrm{mg} \mathrm{L}^{-1}$ myo-inositol, $20 \mathrm{~g} \mathrm{~L}^{-1}$ sucrose, and $2.5 \mathrm{~g} \mathrm{~L}^{-1}$ Phytagel (Sigma-Aldrich, St. Louis, MO, USA). Cultures were kept in a climate room at $26 \pm 2^{\circ} \mathrm{C}$ under a 16 -h photoperiod and light intensity of $55 \mu \mathrm{mol} \mathrm{m}{ }^{-2} \mathrm{~s}^{-1}$.

Isolation and culture of protoplasts. Protoplasts were isolated and cultured according to a previously established protocol (Grzebelus et al. 2012). Briefly, approximately $1 \mathrm{~g}$ of leaves with petioles of 3- to 4-wk-old plantlets were sliced into small pieces in $0.5 \mathrm{M}$ mannitol solution and incubated for $1 \mathrm{~h}$. Enzymatic release of protoplasts took place overnight (14 $16 \mathrm{~h}$ ) on a rotary shaker (30 rpm) in a solution consisting of $1 \%(w / v)$ cellulase Onozuka R-10 (Duchefa Biochemie, Haarlem, The Netherlands), $0.1 \%(w / v)$ pectolyase Y-23 (Duchefa), $20 \mathrm{mM}$ 2-(N-morpholino)ethanesulfonic acid (MES, Sigma), $5 \mathrm{mM} \mathrm{CaCl}_{2}$, and $0.6 \mathrm{M}$ mannitol (Sigma), pH 5.6, filter-sterilized ( $0.22 \mu \mathrm{m}$; Millipore, Billerica, MA). Both plasmolysis of the source tissue before enzyme treatment and enzymatic digestion were conducted in the dark at $26 \pm 2{ }^{\circ} \mathrm{C}$. Then, the mixture was sieved through an $80-\mu \mathrm{m}$ nylon mesh (Millipore) and centrifuged at $100 \mathrm{~g}$ for $5 \mathrm{~min}$. The pellet was resuspended in $8 \mathrm{~mL}$ of $0.5 \mathrm{M}$ sucrose with $1 \mathrm{mM}$ MES and overlaid with $2 \mathrm{~mL}$ of W5 medium (Menczel et al. 1981). Following centrifugation at $145 \mathrm{~g}$ for $10 \mathrm{~min}$, 
intact protoplasts suspended at the solute gradient interface were collected and washed twice by resuspending in W5 solution and the culture medium, respectively, and centrifuged at $100 \mathrm{~g}$ for $5 \mathrm{~min}$ after each wash. The working protoplast density was estimated using a Fuchs Rosenthal hemocytometer and adjusted to $8 \times 10^{5}$ protoplasts per milliliter. Then, the protoplasts were immobilized in modified thin calcium alginate layers at a final plating density of $4 \times 10^{5} \mathrm{~mL}^{-1}$ and cultured in the CPP medium consisting of macro-, microelements, and organic acids according to Kao and Michayluk (1975), vitamins according to B5 medium (Gamborg et al. 1968), $74 \mathrm{~g} \mathrm{~L}^{-1}$ glucose, $250 \mathrm{mg} \mathrm{L}^{-1}$ casein enzymatic hydrolysate (Sigma), $0.1 \mathrm{mg} \mathrm{L}^{-1} 2,4$ dichlorophenoxyacetic acid (2,4-D), and $0.2 \mathrm{mg} \mathrm{L}^{-1}$ zeatin ( $\mathrm{pH}$ 5.6, filter-sterilized). The cultures were incubated in the dark at $26 \pm 2^{\circ} \mathrm{C}$. The medium was replenished every $10 \mathrm{~d}$.

Antibiotics. Three types of $\beta$-lactam antibiotics were used in the experiments: cefotaxime sodium (Polfa-Tarchomin S.A., Warszawa, Poland), carbenicillin disodium (Duchefa), and timentin (ticarcillin disodium/clavulanate potassium $=1,500$ / 100; GlaxoSmithKline, London, UK). They were dissolved in double distilled water, filter-sterilized $(0.22 \mu \mathrm{m}$, Millipore), and stored until use at $-20^{\circ} \mathrm{C}$. Working solutions of antibiotics were applied individually to the protoplast culture medium in five different concentrations: 100, 200, 300, 400, or $500 \mathrm{mg} \mathrm{L}^{-1}$. After $10 \mathrm{~d}$ of culture (simultaneously with refreshment of the medium), antibiotics were applied again.

Plant regeneration. All steps involving plant regeneration were the same as those presented by Grzebelus et al. (2012). Briefly, after 2 mo of culture in the dark at $26 \pm 2^{\circ} \mathrm{C}$, both proembryonic mass (PEM) and somatic embryos emerging from an alginate matrix in antibiotic-treated and control combinations were released from Ca-alginate layers by incubation in a sodium citrate solution. Following two rounds of centrifugation, the pellet finally consisted of callus and embryos free from alginate residue and citrate solution, and was carefully resuspended in the CPPD medium (1/4-strength macro-, micro-elements, and organic acids according to Kao and Michayluk [1975], vitamins according to B5 medium [Gamborg et al. 1968], $30 \mathrm{~g} \mathrm{~L}^{-1}$ sucrose, $20 \mathrm{~g} \mathrm{~L}^{-1}$ mannitol, and $250 \mathrm{mg} \mathrm{L}^{-1}$ casein enzymatic hydrolysate [Sigma], $0.1 \mathrm{mg} \mathrm{L}^{-1} \mathrm{NAA}$ and $0.2 \mathrm{mg} \mathrm{L}^{-1}$ zeatin, $\mathrm{pH}$ 5.6) and plated on filter paper placed on the solidified R medium. Approximately 2-3 wk later, small-rooted plantlets were transferred to a fresh $\mathrm{R}$ medium for further growth. During plant regeneration, the cultures were maintained in a climate room at $26 \pm$ $2{ }^{\circ} \mathrm{C}$ under a 16-h photoperiod and light intensity of $55 \mu \mathrm{mol} \mathrm{m}{ }^{-2} \mathrm{~s}^{-1}$.

Data collection and statistical analysis. To assess the effect of the selected antibiotics on protoplast growth, ability of the protoplast-derived cells to form aggregates was determined. For that purpose, $20 \mathrm{~d}$ after antibiotic application, plating efficiency was estimated and expressed as the number of cell aggregates per the total number of observed undivided cells and cell aggregates $(\times 100)$. All microscopic observations were performed under an Axiovert S100 microscope (Carl Zeiss, Göttingen, Germany). During the regeneration step for each antibiotic-treated and control culture, the number of completely regenerated and normal plants per alginate layer was scored.

All experiments were carried out with at least two replications, each treatment being represented by three Petri dishes (for protoplast cultures) or at least three glass jars (for regeneration). For plating efficiency, counting was carried out in four microscopic fields on 200-600 cells per Petri dish. Mean values and standard errors were calculated. The overall effect of treatments was assessed using the analysis of variance (ANOVA) and Duncan's honestly significant difference (HSD) test in Statistica 9.0 (StatSoft Inc. 2009). Additionally, for each accession, in order to estimate the relationships between concentrations of antibiotic and plating efficiency, analysis of linear regression was performed. The coefficient of determination $\left(R^{2}\right)$ and Pearson's correlation coefficient $(r)$ were calculated to measure goodness of fit of a statistical model and the strength and direction of the linear relationship, respectively.

\section{Results}

Plating efficiency in the culture without antibiotics. Around the third and fourth day of culture, some protoplasts had enlarged and started to change from a spherical to oval shape indicating a reconstruction of the cell wall, and in 5-d-old cultures, first mitotic divisions were observed. Cell divisions took place regularly, and in 20-d-old cultures, cell colonies of different sizes appeared with an average frequency of $52.4 \pm$ $4.8 \%$ (Table 1). The plating efficiency varied from $42 \%$ for 'Amsterdamska' to $65 \%$ for 'Dolanka.' Even though the difference was marginally insignificant $(P=.06)$.

Table 1 Plating efficiency of carrot donor accessions in a culture medium without antibiotics

Plating efficiency $(\% \pm \mathrm{SE})$

\begin{tabular}{llll}
\hline Accession & & \multirow{2}{*}{ Mean } \\
\hline Dolanka & Amsterdamska & Koral & \\
\hline $64.5 \pm 7.4 \mathrm{a}$ & $41.8 \pm 8.6 \mathrm{a}$ & $42.7 \pm 4.7 \mathrm{a}$ & $52.4 \pm 4.8$ \\
\hline
\end{tabular}

Means with the same letters were not significantly different at $P \leq .05$ 
Effect of antibiotics on plating efficiency. The proportion of cell colony formation was highly dependent on the protoplast donor accession as well on the type and concentration of antibiotic $(P \leq .001)$. Twenty days after antibiotic application to the culture medium, the plating efficiency for 'Dolanka'derived protoplasts was approximately 1.5 -fold higher than that for 'Amsterdamska' and 'Koral' reaching 50, 31, and $29 \%$, respectively (Table 2). Of the antibiotics used, cefotaxime showed the least toxic effect on cell division frequency, while in the presence of carbenicillin and timentin, almost a twofold decrease was observed $(P<.001$; data not shown). Supplementation of the culture medium with antibiotic in the range of 200 to $500 \mathrm{mg} \mathrm{L}^{-1}$ reduced the plating efficiency in comparison to controls on average from 41 to $25 \%$, respectively (Table 2).

Both the type and concentration of antibiotic affected the number of cell colonies with respect to protoplast donor accessions $(P \leq .01$; Table 2$)$. In general, cefotaxime was associated with the least negative influence on plating efficiency. In such conditions, the number of protoplast-derived cell colonies ranged from $37 \%$ for 'Koral' to $63 \%$ for 'Dolanka' and 'Amsterdamska'. The most toxic effects on mitotic divisions were observed after exposing 'Amsterdamska'-derived protoplasts to carbenicillin and timentin and 'Koral'-derived protoplasts to carbenicillin (Table 2). In cefotaximecontaining medium, at a concentration of $0-500 \mathrm{mg} \mathrm{L}^{-1}$, differences in the level of colony formation were not significant $(P=.63)$. In carbenicillin- and timentin-containing media, concentrations of antibiotics higher than 300 and $400 \mathrm{mg} \mathrm{L}{ }^{-1}$, respectively, resulted in reductions in plating efficiency in comparison to antibiotic-free medium. A very strong linear reduction in plating efficiency with increasing of antibiotic concentration was recorded for all accessions in carbenicillin-containing media as well for 'Dolanka' in cefotaxime-containing medium and for 'Amsterdamska' and 'Koral' in timentin-containing medium $\left(R^{2}=0.7-1.0, P<.05\right.$; Fig. 1$)$. A similar tendency, but marginally non-significant $(P=.07)$, was observed for 'Koral' in cefotaxime-containing medium.

Plant regeneration from antibiotic-treated protoplast cultures. During 2 mo of culture in antibiotic-free media, continuous growth of cell colonies in alginate layers took place leading to the formation of microcalli, macrocalli, and proembryonic masses (PEM) in all accessions. PEM easily transformed in sequence into globular, torpedo-shaped, and cotyledonary-stage somatic embryos. On antibioticcontaining media, efficiency of callus and embryo formation varied among accessions, antibiotic type, and concentration (data not shown). Plant regeneration occurred after depolymerization of alginate matrix and transfer of released tissue masses onto hormone- and antibiotic-free media. Similar to calli and PEM development, the number of regenerated plants highly depended on protoplast donor accession and type of antibiotic used during protoplast culture $(P<.001)$. On average, the highest number of plants $(54.4 \pm 4.5)$ was achieved from 'Dolanka'-derived protoplast cultures, while almost twofold fewer plants were regenerated from 'Koral'- and 'Amsterdamska'-derived protoplast cultures $(29.2 \pm 4.2$ and $24.9 \pm 2.5$, respectively; Table 3 ). Such a trend in regeneration efficiency from donor accessions was observed for cefotaxime-, carbenicillin-, and timentin-containing protoplast cultures $(P<.001 ;$ Fig. 2$)$. The production of plants was strongly affected by antibiotic treatment during protoplast cultures reaching on average the highest number from cefotaxime-containing protoplast cultures $(47.1 \pm 4.0$; Table 3$)$
Table 2 Average effect of type and concentration of antibiotics on plating efficiency in 20-d-old protoplast cultures of different carrot accessions

In each section of the table, means with the same letters did not differ significantly $(P \leq .001)$ within each column

${ }^{\mathrm{a}}$ The means represent averages of all concentrations

${ }^{\mathrm{b}}$ The means represent averages of the three accessions

\begin{tabular}{|c|c|c|c|c|}
\hline \multirow[t]{3}{*}{ Factor } & \multicolumn{3}{|c|}{ Plating efficiency $(\% \pm \mathrm{SE})$} & \multirow[t]{3}{*}{ Mean } \\
\hline & \multicolumn{3}{|l|}{ Antibiotic } & \\
\hline & Cefotaxime & Carbenicillin & Timentin & \\
\hline \multicolumn{5}{|l|}{ Accession $^{\mathrm{a}}$} \\
\hline Dolanka & $62.6 \pm 3.6 \mathrm{a}$ & $43.1 \pm 7.0 \mathrm{a}$ & $37.9 \pm 2.5 \mathrm{a}$ & $49.8 \pm 3.4 \mathrm{a}$ \\
\hline Amsterdamska & $62.7 \pm 1.3 \mathrm{a}$ & $8.9 \pm 2.3 \mathrm{~b}$ & $22.7 \pm 3.3 \mathrm{~b}$ & $31.4 \pm 4.1 \mathrm{~b}$ \\
\hline Koral & $36.7 \pm 3.1 \mathrm{~b}$ & $12.5 \pm 4.3 \mathrm{~b}$ & $36.8 \pm 3.8 \mathrm{a}$ & $28.6 \pm 2.9 \mathrm{~b}$ \\
\hline \multicolumn{5}{|c|}{ Concentration of antibiotic ${ }^{\mathrm{b}}\left(\mathrm{mg} \mathrm{L}^{-1}\right)$} \\
\hline 0 & $60.5 \pm 7.3 \mathrm{a}$ & $50.1 \pm 10.4 \mathrm{a}$ & $44.6 \pm 4.7 \mathrm{a}$ & $52.4 \pm 4.8 \mathrm{a}$ \\
\hline 100 & $61.3 \pm 5.9 \mathrm{a}$ & $40.3 \pm 10.9 \mathrm{ab}$ & $36.0 \pm 3.8 \mathrm{ab}$ & $46.7 \pm 5.0 \mathrm{ab}$ \\
\hline 200 & $57.7 \pm 5.5 \mathrm{a}$ & $31.4 \pm 10.8 \mathrm{abc}$ & $31.7 \pm 5.2 \mathrm{ab}$ & $41.0 \pm 5.2 \mathrm{bc}$ \\
\hline 300 & $56.2 \pm 6.3 \mathrm{a}$ & $22.7 \pm 10.6 \mathrm{abc}$ & $30.6 \pm 5.6 \mathrm{ab}$ & $37.1 \pm 5.6 \mathrm{bc}$ \\
\hline 400 & $53.0 \pm 6.3 \mathrm{a}$ & $13.7 \pm 9.4 \mathrm{bc}$ & $27.4 \pm 5.3 \mathrm{ab}$ & $31.7 \pm 5.6 \mathrm{~cd}$ \\
\hline 500 & $48.1 \pm 6.9 \mathrm{a}$ & $3.0 \pm 1.9 \mathrm{c}$ & $24.7 \pm 5.2 \mathrm{~b}$ & $25.3 \pm 5.1 \mathrm{~d}$ \\
\hline
\end{tabular}


cefotaxime

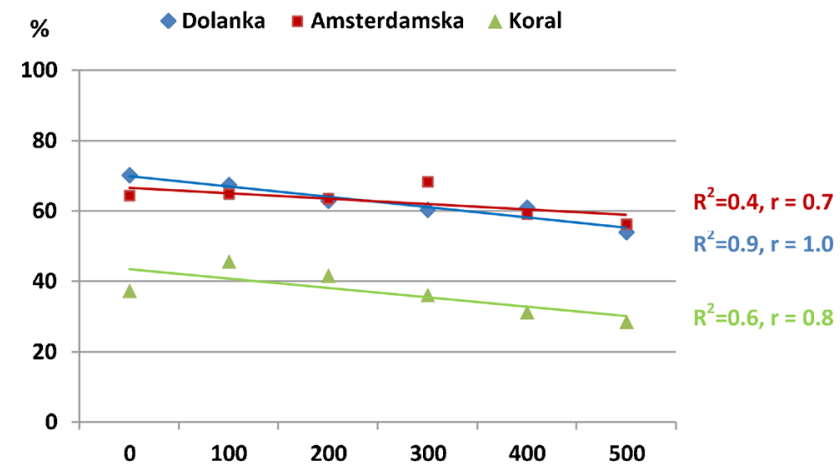

carbenicillin

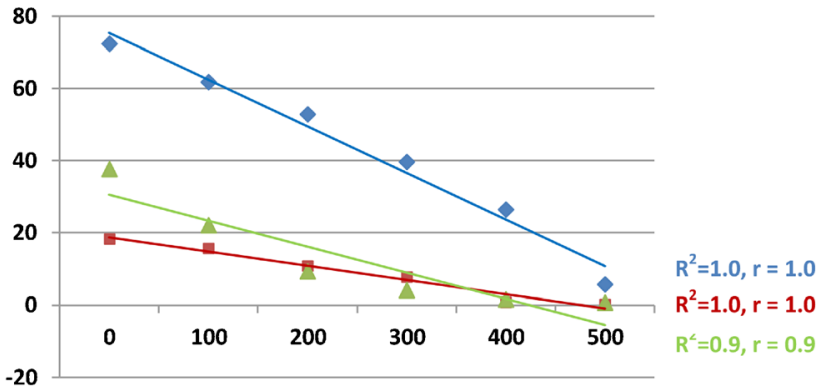

timentin

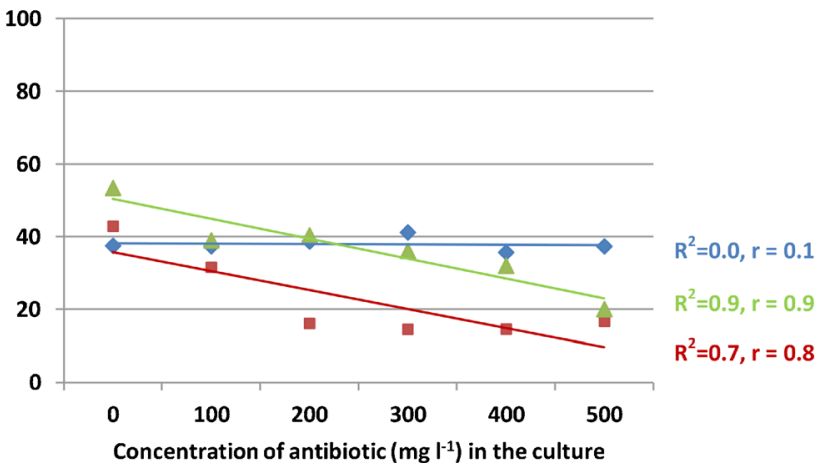

Figure 1. Plating efficiency in 20-d-old protoplast-derived cultures of three carrot accessions in antibiotic-containing media. $R^{2}$ coefficient of determination, $r$ Pearson's correlation coefficient.

and the lowest from carbenicillin-containing protoplast cultures (27.1 \pm 4.1$)$. Various concentrations of antibiotics applied to protoplast cultures differentially influenced plant production (Fig. 2). Exposure of protoplast cultures to 400 $500 \mathrm{mg} \mathrm{L}^{-1}$ cefotaxime showed a stimulatory effect on plant production in comparison to the control combination (65-66 plants and 40 plants, respectively). On the other hand, 400$500 \mathrm{mg} \mathrm{L}^{-1}$ carbenicillin applied to protoplast cultures completely reduced the ability of protoplast-derived tissues to regenerate. However, exposure of protoplast cultures to $200 \mathrm{mg} \mathrm{L}^{-1}$ carbenicillin resulted in more plants in comparison to carbenicillin-free protoplast cultures (47 and 36 plants, respectively). For timentin-containing protoplast cultures, a decrease in plant production was observed at a concentration
Table 3 Mean effect of donor accession, antibiotic, and concentration of antibiotic on plant regeneration from antibiotic-treated protoplast cultures

\begin{tabular}{lcc} 
& Amsterdamska & $24.9 \pm 2.5 \mathrm{~b}$ \\
& Koral & $29.2 \pm 4.2 \mathrm{~b}$ \\
Antibiotic & \\
& Cefotaxime & $47.1 \pm 4.0 \mathrm{a}$ \\
Carbenicillin & $27.1 \pm 4.1 \mathrm{c}$ \\
& Timentin & $34.3 \pm 4.1 \mathrm{~b}$ \\
& Concentration of antibiotic $\left(\mathrm{mg} \mathrm{L}^{-1}\right)$ \\
& 0 & $37.0 \pm 2.8 \mathrm{a}$ \\
& 100 & $36.1 \pm 3.3 \mathrm{a}$ \\
& 200 & $37.3 \pm 4.9 \mathrm{a}$ \\
Means followed by the & 300 & $35.7 \pm 5.8 \mathrm{a}$ \\
same letters did not differ & 500 & $34.1 \pm 7.9 \mathrm{a}$ \\
significantly $(P \leq .05)$ & 500 & $36.8 \pm 9.0 \mathrm{a}$ \\
\hline
\end{tabular}

of $200 \mathrm{mg} \mathrm{L}^{-1}$, while all other concentrations did not influence the regeneration efficiency (Fig. 2).

Strong associations between donor accession, type of antibiotic, and their concentration applied during protoplast culture on plant regeneration were recorded $(P<.001)$. For cefotaxime-containing protoplast cultures, an increase in plant production was observed at a concentration of 400 $500 \mathrm{mg} \mathrm{L}^{-1}$ in 'Koral'-derived protoplast cultures, while for 'Dolanka' and 'Amsterdamska' application of cefotaxime to protoplast cultures showed no effect on subsequent plant regeneration (Fig. 2). Carbenicillin present in protoplast culture media at concentrations of $400-500$ and $300-500 \mathrm{mg} \mathrm{L}^{-1}$ negatively affected plant regeneration for 'Dolanka'/ 'Amsterdamska' and 'Koral', respectively. However, a higher regeneration efficiency was recorded from 'Dolanka'-derived protoplast cultures containing $200-300 \mathrm{mg} \mathrm{L}^{-1}$ carbenicillin in comparison to the controls. Timentin applied to 'Dolanka'and 'Amsterdamska'-derived protoplast cultures at concentrations of $400-500 \mathrm{mg} \mathrm{L}^{-1}$ stimulated and reduced plant production, respectively, while supplementation of 'Koral'-derived protoplast cultures with timentin had no effect on plant regeneration.

\section{Discussion}

Despite bacteriostatic (suppression of bacteria growth) and bactericidal (killing of bacteria) effects, antibiotics may behave as plant growth regulators and positively or negatively affect callus induction (Qin et al. 2011), plant morphogenesis (Qin et al. 2011), shoot formation (Dai and Castillo 2007), 


\section{cefotaxime}

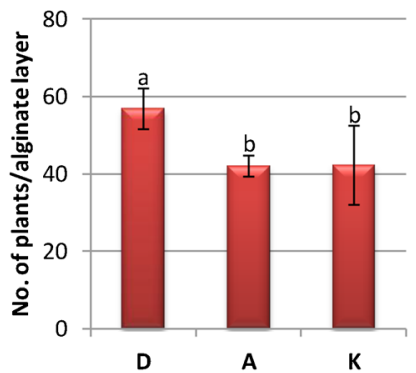

carbenicillin

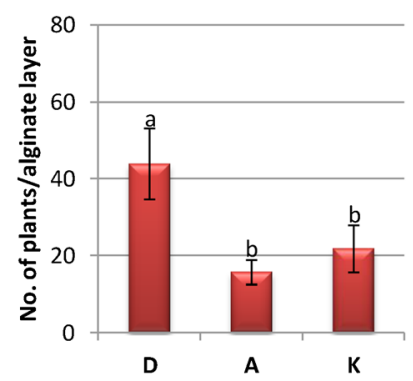

timentin
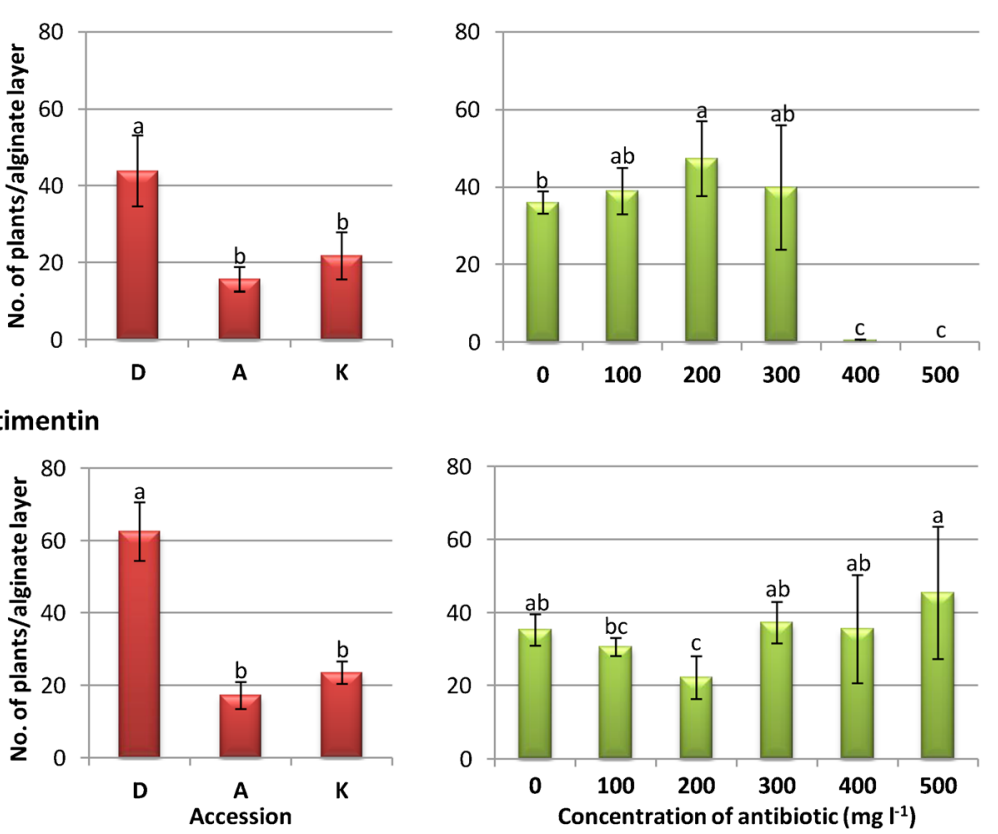
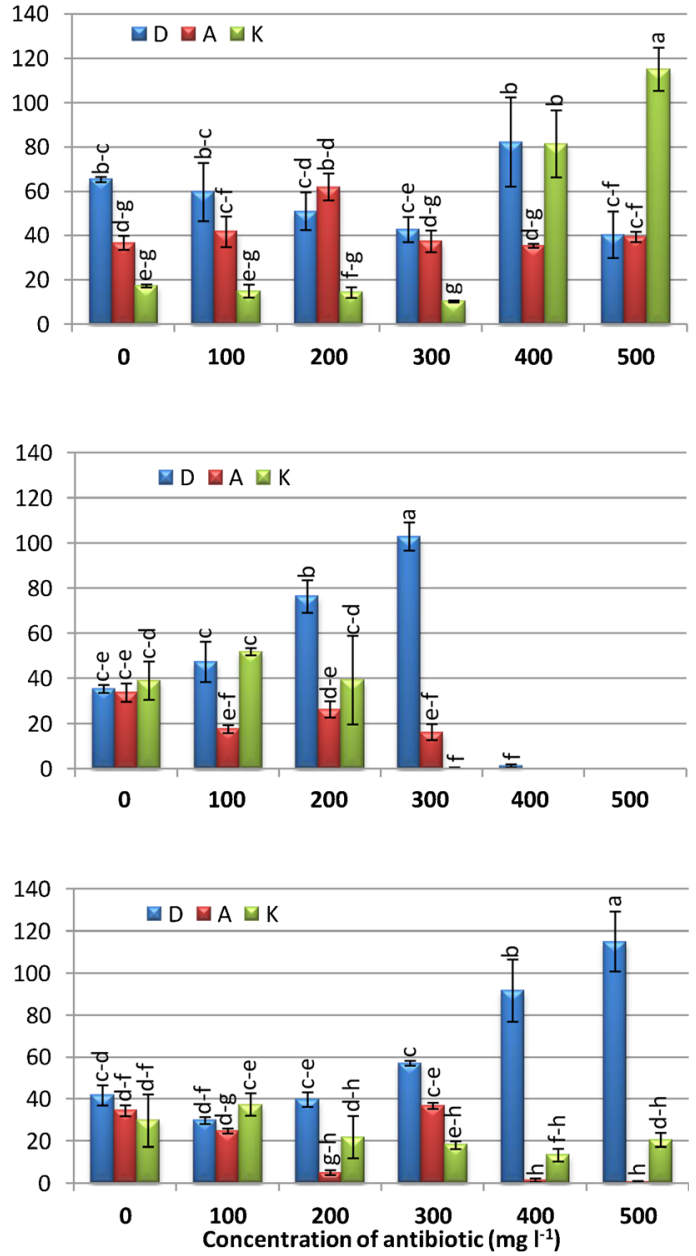

Figure 2. Effect of $\beta$-lactam antibiotics on plant regeneration of different carrot accessions from cefotaxime-, carbenicillin-, and timentincontaining protoplast culture media. Bars represent the standard error.
$D$ 'Dolanka', $A$ 'Amsterdamska', $K$ 'Koral'. Means denoted by different letters are significantly different $(P \leq .001)$.

triticale (Asif et al. 2013). The activity of cefotaxime in the culture may be attributed to the fact that plant esterases degrade it to produce new metabolites that may have growth regulatory properties (Mathias and Boyd 1986). Since a reduced number of albino shoots was observed on cefotaximecontaining media, it has been speculated that cefotaxime can act at the level of chlorophyll synthesis and, thus, boost the photosynthetic machinery (Grewal et al. 2006). In addition to this, cefotaxime might inhibit ethylene production in the cultures, which is positively correlated with plantlet differentiation from the callus mass (Pius et al. 1993). In contrast, results presented here showed a neutral effect of cefotaxime at all tested concentrations during the early stages of culture ( $2 \mathrm{wk}$ old) since the mitotic activity of carrot protoplast-derived cells was similar to that observed in control cultures. Both Pollock et al. (1983) and Simmonds and Grainger (1993) analyzed the plating efficiency in older 4-wk-old protoplast cultures of N. plumbaginifolia and T. aestivum, respectively, and concluded that cefotaxime was not toxic up to levels of $100 \mathrm{mg} \mathrm{L}^{-1}$. 
However, during further stages of development (i.e., in 4- to 8wk-old cultures) the presence of cefotaxime at higher concentrations could positively influence somatic embryogenesis, which was reflected here in the higher number of plants produced from proembryogenic masses derived from carrot protoplast cultures supplemented with $400-500 \mathrm{mg} \mathrm{L}^{-1}$ cefotaxime. Similarly, application of $500 \mathrm{mg} \mathrm{L}^{-1}$ cefotaxime to callus cultures of sugarcane promoted somatic embryogenesis and subsequent plant regeneration (Mittal et al. 2009).

Carbenicillin exhibited dual (stimulatory and inhibitory) impacts on different plant explants (Qin et al. 2011). This is because carbenicillin possesses an auxin-like structure, and in culture media, it is broken down to physiologically active auxin phenylacetic acid at levels sufficient to induce auxin-mediated responses (Holford and Newbury 1992). In somatic embryo cultures of walnut, carbenicillin at $100-1,000 \mathrm{mg} \mathrm{L}^{-1}$ slightly reduced the production of secondary somatic embryos (Tang et al. 2000). Very little growth of callus tissue from root explants of carrots in the presence of $300 \mathrm{mg} \mathrm{L}^{-1}$ carbenicillin in the culture medium was also reported (Chang and Schmidt 1991). Our results demonstrated that in early cultures, carbenicillin at concentrations of $400-500 \mathrm{mg} \mathrm{L}^{-1}$ reduced the mitotic activity of carrot protoplast-derived cells gradually leading to complete arrest of cell divisions in older cultures, and as a result, a lack of plant regeneration was observed. Yu and Wei (2008) showed that application of carbenicillin to the culture media even at a concentration of $100 \mathrm{mg} \mathrm{L}^{-1}$ strongly inhibited plant regeneration from the embryogenic calli of wheat. However, in leaf cultures of horseradish, carbenicillin appeared as a growth enhancer promoting regeneration of adventitious shoots at a concentration of $100 \mathrm{mg} \mathrm{L}^{-1}$ and the formation of somatic embryos at concentrations up to $500 \mathrm{mg} \mathrm{L}^{-1}$ (Shehata et al. 2010). Similarly, in the present research, a positive effect of carbenicillin application to the protoplast cultures at a concentration of $200 \mathrm{mg} \mathrm{L}^{-1}$ on regeneration was observed and more plants in comparison with control was produced.

Timentin is one of the novel $\beta$-lactams developed recently to enhance antibacterial activity (Demain and Elander 1999). It is composed of ticarcillin coupled with the $\beta$-lactamase inhibitor clavulanic acid. Since ticarcillin, belonging to the penicillin group antibiotics, has a similar chemical structure as that of penicillin $\mathrm{G}$, it is metabolized in a similar fashion as carbenicillin to phenylacetic acid, a naturally occurring weak auxin (Nauerby et al. 1997; da Silva Mendes et al. 2009). Thus, in addition to its broad-spectrum antimicrobial activity, timentin may differentially affect the growth and development of plant explants. The enhancement of organogenesis has been observed on leaf explants of N. tabacum (Nauerby et al. 1997) and cotyledon explants of tomatoes (Costa et al. 2000) at concentrations of 150 and $300 \mathrm{mg} \mathrm{L}^{-1}$, respectively. The same concentrations of timentin showed beneficial effects on shoot regeneration in epicotyl explant cultures of sweet oranges (da Silva Mendes et al. 2009). In walnut cultures (Tang et al. 2000), doses lower than $500 \mathrm{mg} \mathrm{L}^{-1}$ had a non-detrimental influence on secondary somatic embryogenesis, whereas in cacao cultures (Silva et al. 2009), timentin at $300 \mathrm{mg} \mathrm{L}^{-1}$ was associated with a reduced production of somatic embryos. Out of five concentrations of timentin compared in the present study, 500 and $200 \mathrm{mg} \mathrm{L}^{-1}$ reduced the formation of cell aggregates and plant regeneration from protoplast-derived cells, respectively, while the remaining concentrations did not exhibit any developmental effects.

Occasional contaminations are most often introduced to cultures randomly by the operator and are usually represented by the genus Staphylococcus residing preferentially on human skin scales (Trudeau and Fernández-Caldaz 1994). However, these bacterial isolates can be successfully controlled by cefotaxime at a concentration of $100 \mathrm{mg} \mathrm{L}^{-1}$ (Asif et al. 2013). In Agrobacterium-mediated transformation, the suppression and elimination of agrobacteria in plant tissue, to enable the regeneration of transformed explants or cells, can be observed after application of cefotaxime at doses of $250-500 \mathrm{mg} \mathrm{L}^{-1}$ (Nauerby et al. 1997; da Silva Mendes et al. 2009) or timentin at doses of 150-500 $\mathrm{mg} \mathrm{L}^{-1}$ (Nauerby et al. 1997; Cheng et al. 1998; Silva et al. 2009). These data may suggest that concentrations of cefotaxime and timentin used in this study could also minimize or eliminate both bacterial contaminations and Agrobacterium tumefaciens from carrot tissue cultures without inducing a phytotoxic effect.

\section{Conclusions}

To our knowledge, this study presents the first report evaluating the effect of cefotaxime, carbenicillin, and timentin on plant regeneration in carrot protoplast cultures. Supplementation of protoplast culture media with cefotaxime or timentin in the range of $100-500 \mathrm{mg} \mathrm{L}^{-1}$ was essentially non-toxic to the cells and enabled further plant regeneration at high efficiency. Thus, we believe that these antibiotics may be routinely used during complex in vitro procedures or in valuable or irreplaceable carrot cultures to prevent them against unwanted and accidental bacterial contaminations. Additionally, cefotaxime and timentin can also be antibiotics of choice to control Agrobacterium growth in experiments on genetic transformation of carrots since they exhibit non-detrimental effects on somatic embryogenesis and plant regeneration in protoplast cultures.

Acknowledgment This work was supported by statutory funds for science DS3500 granted by the Polish Ministry of Science and Higher Education.

Open Access This article is distributed under the terms of the Creative Commons Attribution License which permits any use, distribution, and reproduction in any medium, provided the original author(s) and the source are credited. 


\section{References}

Abdi G, Salehi H, Khosh-Khui M (2008) Nano silver: a novel nanomaterial for removal of bacterial contaminants in valerian (Valeriana officinalis L.) tissue cultures. Acta Physiol Plant 30: 709-714

Asif M, Eudes F, Randhawa H, Amundsen E, Yanke J, Spaner D (2013) Cefotaxime prevents microbial contamination and improves microspore embryogenesis in wheat and triticale. Plant Cell Rep 32:16371646

Chang CC, Schmidt DR (1991) Initiation and proliferation of carrot callus using a combination of antibiotics. Planta 185:523-526

Cheng ZM, Schnurr JA, Kapaun JA (1998) Timentin as an alternative antibiotic for suppression of Agrobacterium tumefaciens in genetic transformation. Plant Cell Rep 17:646-649

Costa MGC, Nogueira FTS, Figueira ML, Otoni WC, Brommonschenkel SH, Cecon PR (2000) Influence of the antibiotic Timentin on plant regeneration of tomato (Lycopersicon esculentum Mill.) cultivars. Plant Cell Rep 19:327-332

d'Utra Vaz FB, dos Santos AVP, Manders G, Cocking EC, Davey MR, Power JB (1993) Plant regeneration from leaf mesophyll protoplasts of the tropical woody plant, passionfruit (Passiflora edulis $\mathrm{fv}$ flavicarpa Degener.): the importance of the antibiotic cefotaxime in the culture medium. Plant Cell Rep 12:220-225

da Silva Mendes AF, Cidale LC, de Oliveira MLP, Otoni WC, SoaresFilho WDS, Costa MGC (2009) Evaluation of novel beta-lactam antibiotics in comparison to cefotaxime on plant regeneration of Citrus sinensis L. Osb. Plant Cell Tissue Organ Cult 97:331-336

da Silva JAT, Fukai S (2003) Effect of aminoglycoside antibiotics on invitro morphogenesis from cultured cells of chrysanthemum and tobacco. J Plant Biol 46:71-82

Dai W, Castillo C (2007) Factors affecting plant regeneration from leaf tissues of Buddleia species. Hortscience 42:1509-1517

Danilova SA, Dolgikh YI (2004) The stimulatory effect of the antibiotic cefotaxime on plant regeneration in maize tissue culture. Russ $\mathrm{J}$ Plant Physiol 51:621-625

Davey MR, Anthony P, Power JB, Lowe KC (2005a) Plant protoplast technology: current status. Acta Physiol Plant 27:117-129

Davey MR, Anthony P, Power JB, Lowe KC (2005b) 2004 SIVB congress symposium proceedings "Thinking outside the cell": plant protoplast technology: status and applications. In Vitro Cell Dev Biol Plant 41:202-212

Demain AL, Elander RP (1999) The $\beta$-lactam antibiotics: past, present, and future. Antonie Van Leeuwenhoek 75:5-19

Fellner M (1995) Influence of the antibiotic ciprofloxacin on culture of Allium longicuspis callus-derived protoplasts. Ann Bot 76:219-223

Gamborg OL, Miller RA, Ojima K (1968) Nutrient requirements of suspension cultures of soybean root cells. Exp Cell Res 50:151-158

Grewal D, Gill R, Gosal SS (2006) Influence of antibiotic cefotaxime on somatic embryogenesis and plant regeneration in indica rice. Biotechnol J 1:1158-1162

Grzebelus E, Szklarczyk M, Baranski R (2012) An improved protocol for plant regeneration from leaf and hypocotyl-derived protoplasts of carrot. Plant Cell Tissue Organ Cult 109:101-109

Holford P, Newbury HJ (1992) The effects of antibiotics and their breakdown products on the in vitro growth of Antirrhinum majus. Plant Cell Rep 11:93-96

Jiang F, Zhu J, Liu HL (2013) Protoplasts: a useful research system for plant cell biology, especially dedifferentiation. Protoplasma. doi:10. 1007/s00709-013-0513-z

Kao KN, Michayluk MR (1975) Nutritional requirements for growth of Vicia hajastana cells and protoplasts at a very low population density in liquid media. Planta 126:105-110
Kaur A, Gill MS, Ruma D, Gosal SS (2008) Enhanced in vitro shoot multiplication and elongation in sugarcane using cefotaxime. Sugar Tech 10:60-64

Leifert C, Cassells AC (2001) Microbial hazards in plant tissue and cell cultures. In Vitro Cell Dev Biol Plant 37:133-138

Leifert C, Waites WM (1992) Bacterial growth in plant tissue culture media. J Appl Bacteriol 72:460-466

Mathias RJ, Boyd LA (1986) Cefotaxime stimulates callus growth, embryogenesis and regeneration in hexaploid bread wheat (Triticum aestivum L. cm. Thell). Plant Sci 46:217-223

Menczel L, Nagy F, Kiss Z, Maliga P (1981) Streptomycin resistant and sensitive somatic hybrids of Nicotiana tabacum (x) Nicotiana knightiana: correlation of resistance to $N$. tabacum plastids. Theor Appl Genet 70:590-594

Mittal P, Gosal SS, Senger A, Kumar P (2009) Impact of cefotaxime on somatic embryogenesis and shoot regeneration in sugarcane. Physiol Mol Biol Plant 15:257-265

Murashige T, Skoog F (1962) A revised medium for rapid growth and bioassays with tobacco tissue culture. Physiol Plant 18:100-127

Nauerby B, Billing K, Wyndaele R (1997) Influence of the antibiotic Timentin on plant regeneration compared to carbenicillin and cefotaxime in concentrations suitable for elimination of Agrobacterium tumefaciens. Plant Sci 123:169-177

Ogawa Y, Mii M (2004) Screening for highly active $\beta$-lactam antibiotics against Agrobacterium tumefaciens. Arch Microbiol 181:331-336

Pius J, George L, Eapen S, Rao PS (1993) Enhanced plant regeneration in pearl millet (Pennisetum americanum) by ethylene inhibitors and cefotaxime. Plant Cell Tissue Organ Cult 32:91-96

Pollock K, Barfield DG, Shields R (1983) The toxicity of antibiotics to plant cell cultures. Plant Cell Rep 2:36-39

Qin YH, Teixeira da Silva JA, Bi JH, Zhang SL, Hu GB (2011) Response of in vitro strawberry to antibiotics. Plant Growth Regul 65:183-193

Rahman LU, Ikenaga T, Kitamura Y (2004) Penicillin derivatives induce chemical structure-dependent root development, and application for plant transformation. Plant Cell Rep 22:668-677

Shehata AM, Wannarat W, Skirvin RM, Norton MA (2010) The dual role of carbenicillin in shot regeneration and somatic embryogenesis of horseradish (Armoracia rusticana) in vitro. Plant Cell Tissue Organ Cult 102:397-402

Silva TER, Cidade LC, Alvim FC, Cascardo JCM, Costa MGC (2009) Studies on genetic transformation of Theobroma cacao L.: evaluation of different polyamines and antibiotics on somatic embryogenesis and the efficiency of uidA gene transfer by Agrobacterium tumefaciens. Plant Cell Tissue Organ Cult 99:287-298

Simmonds JA, Grainger JL (1993) The toxicity of antibiotics to protoplast cultures of Triticum aestivum L. Plant Sci 89:209-214

StatSoft Inc (2009) STATISTICA (data analysis software system), version 9. www.statsoft.com. Cited 2 Sep 2013

Tang H, Ren Z, Krczal G (2000) An evaluation of antibiotics for the elimination of Agrobacterium tumefaciens from walnut somatic embryos and for the effects on the proliferation of somatic embryos and regeneration of transgenic plants. Plant Cell Rep 19:881-887

Teng WL, Nicholson L (1997) Pulse treatments of penicillin-G and streptomycin minimize internal infections and have post-treatment effects on the morphogenesis of ginseng root culture. Plant Cell Rep 16:531-535

Trudeau WL, Fernández-Caldaz E (1994) Identifying and measuring indoor biologic agents. J Allergy Clin Immunol 94:393-400

Watts JW, King JM (1973) The use of antibiotics in the culture of nonsterile plant protoplasts. Planta 113:271-277

Yu Y, Wei ZM (2008) Influences of cefotaxime and carbenicillin on plant regeneration from wheat mature embryos. Biol Plant 52:553-556 